\title{
Bidirectional Promoter of Human Monoamine Oxidase A (MAO A) Controlled by Transcription Factor Sp1
}

\author{
Qin-shi Zhu, Kevin Chen, and Jean Chen Shih \\ Department of Molecular Pharmacology and Toxicology, School of Pharmacy, University of Southern California, Los \\ Angeles, California 90033
}

\begin{abstract}
The core promoter region of human monoamine oxidase (MAO) A has been identified in the two 90 bp repeat sequences, which can be further divided into four imperfect tandem repeats, each containing an Sp1 binding site in the reversed orientation. Gel retardation and DNase 1 footprinting assays identified Sp1 to be the major transcription factor binding to MAO A core promoter. In addition, positive association has been observed between cellular Sp1 concentration and MAO A promoter or catalytic activity, indicating that Sp1 is a controlling factor for human MAO A expression. DNA fragments from MAO A core promoter exhibit promoter activity in both orientations in a transient transfection assay, using human growth hormone as the reporter gene. A DNA probe isolated from upstream of the core promoter detected positive signals in a Northern analysis, suggesting that the reverse promoter activity may endogenously transcribe a new gene located upstream of MAO A.
\end{abstract}

IKey words: human monoamine oxidase A, bidirectional promoter, Sp1, human growth hormone reporter gene, gel retardation, DNase 1 footprinting, Northern analysis]

Monoamine oxidase $\mathrm{A}$ and $\mathrm{B}$ (MAO A and MAO B; amine : oxygen oxidoreductase, EC 1.4.3.4) catalyze the oxidative deamination of neurotransmitters (von Korff, 1979; Tipton et al., 1987), dietary amines, and the parkinsonism-producing neurotoxin 1-methyl-4-phenyl-1,2,3,6-tetrahydropyridine (MPTP) (Chiba et al., 1984; Fritz et al., 1985). MAO A preferentially oxidizes serotonin and is sensitive to inhibitor clorgyline (Johnston, 1968) whereas MAO B preferentially oxidizes phenylethylamine and benzylamine and is sensitive to inhibitors pargyline and deprenyl (Knoll and Magyar, 1972). Dopamine, tyramine, and tryptamine are common substrates for the two forms of MAO.

The cloning of cDNAs for human liver MAO A and B (Bach et al., 1988) has clearly demonstrated that the two types of the enzyme are made of different primary structure. Further, the deduced amino acid sequences of human brain, platelet, and liver MAO B are identical (Chen et al., 1993). Both MAO A

\footnotetext{
Received Dec. 27, 1993; revised May 3, 1994; accepted May 16, 1994.

We thank Joseph Grimsby for the preliminary Northern analysis in detecting reverse transcripts and $\mathrm{Ms}$. Hui Xu for her technical assistance. This work was supported by Grant R01 MH37020, R37 MH39085 (Merit Award), and Research Scientist Award K05 MH00796, from the National Institute of Mental Health. Support from the Boyd and Elsie Welin Professorship is also appreciated.

Correspondence should be addressed to Jean Chen Shih, Department of Molecular Pharmacology and Toxicology, School of Pharmacy, University of Southern California, 1985 Zonal Avenue, Los Angeles, CA 90033.

Copyright (C) 1994 Society for Neuroscience $0270-6474 / 94 / 147393-11 \$ 05.00 / 0$
}

and $B$ genes consist of 15 exons and exhibit identical exonintron organizations, suggesting that these two genes are derived from duplication of a common ancestral gene (Grimsby et al., 1991). These genes reside closely between bands Xp11.23 to Xp22.1 of the X chromosome (Ozelius et al., 1988; Lan et al., 1989). Recently, MAO A deficiency was found in males with aggressive behavior in a Dutch family (Brunner et al., 1993a,b).

MAO A and B can be detected in most human tissues examined (Grimsby et al., 1990); however, there are tissue- and cell-specific distributions (Yu and Hert7, 1982; Westlund et al., 1985; Youdim et al., 1986). Human placenta expresses predominantly MAO A (Egashira and Yamanaka, 1981; Bach et al., 1988; Grimsby et al., 1990); human platelets and lymphocytes contain only MAO B (Donnelly and Murphy, 1977). In human brain, MAO B is found in astrocytes and serotonergic neurons, while MAO A is expressed in catecholaminergic neurons (Fowler et al., 1987; Thorpe et al., 1987). Furthermore, MAO A and $\mathrm{B}$ expression are also different during development. MAO A activity appears before MAO B activity in fetal brain (Lewinsohn et al., 1980), whereas MAO B activity is higher than MAO $A$ in adult human brain (Garrick and Murphy, 1982).

In order to understand the tissue- and cell-specific expression of MAO A and B, we have characterized the promoter of both MAO A and B genes (Zhu et al., 1992). Sequence homology ( $60 \%$ identity) between MAO A and B promoter indicates that these two promoters may also be derived from duplication. However, none of the transcription factor binding sites are conserved between the two promoters, suggesting that the expression of these two forms of the enzyme have diverged in evolution. The promoter activity of MAO A gene is found in two 90 bp repeats, each containing two $\mathrm{Spl}$ sites in the reversed orientation. Similar findings were reported recently (Denney et al., 1993). MAO B promoter activity resides in a $0.15 \mathrm{~kb}$ Pstl/ NaeI fragment, which contains two groups of overlapping Spl binding sites separated by a CACCC element and followed by a downstream TAATATA box. The different structure of MAO $A$ and $B$ promoter may provide the basis for the observed differential MAO A and $\mathrm{B}$ expression.

Data is presented in this report to demonstrate that $\mathrm{Spl}$ is the major transcription factor interacting with MAO A core promoter and the concentration of $\mathrm{Sp} 1$ in cells appears to be a controlling factor for MAO A expression. In addition, the MAO A core promoter promotes transcription in both orientations and the reverse promoter activity may transcribe endogenously a new gene.

\section{Materials and Methods}

Mapping of transcription initiation site by $5^{\prime} R A C E$. mRNAs from human frontal cortex, cerebellum, liver, small intestine, and aorta smooth 
muscle were purchased from Clontech (Palo Alto, CA). They were reverse transcribed with a polyT primer. The $3^{\prime}$ end of the cDNA molecules was C-tailed through terminal transferase as instructed by the manufacturer (GIBCO-Bethesda Research Labs) of a 5' RACE kit. Two consecutive PCR were performed with a primer targeted to the $\mathrm{C}$ tail and two nested primers specific for MAOA. The primers used for the first round of PCR primers were E7A: 5' GCTCACTTGACCAGATCCACC 3', which bound to a sequence in exon 7 and anchor primer (AP), which contained polyG sequence for the $C$ tail and an adaptor sequence. The product was diluted 10 times for the second round of PCR. The primers used were E3A: 5' CAUCAUCAUCAUGACATATTGAACGAGACGC $3^{\prime}$, which bound to a sequence in MAO A exon 3 and contained four CAU repeats at its $5^{\prime}$ end, and universal anchor primer (UAP), which contained the adaptor sequence in AP and four CAU repeats. The product was cloned into the vector pAMP1 through the four CAU repeats at both ends in the presence of uracil DNA glycosolase supplied by another kit from GIBCO-BRL. The sequence of the inserts was determined and compared with genomic DNA to determine the 5 ' end of MAO A mRNA.

DNA cloning and promoter activity measurement. Most DNA fragments tested for promoter activity were isolated from the subcloned $0.24 \mathrm{~kb}$ PvuII/DralI fragment, which contains the core promoter sequences for human MAO A gene (Zhu et al., 1992). To determine both the forward and the reverse promoter activity, these fragments were linked, in both orientations, to the human growth hormone reporter gene in the promoterless expression vector pOGH (Nichols Diagnosis Institute). This was achieved by first cloning these fragments into pUC 19. They are then isolated from the pUC 19 constructs in HindIII/ BamHI fragments and cloned into the vector pOGH digested with HindIII and BamHI. To insert these fragments conveniently into pOGH in the reversed orientation, a new pOGH vector (named pOGHR) was constructed in which the position of the HindIII site and the BamHI site are reversed. The $0.2 \mathrm{~kb}$ Rsa/Drall fragment, which contains all four $\mathrm{Sp} 1$ sites but without the upstream TAATAA sequence, was resistant to subcloning, possibly due to certain secondary structure at their $\mathbf{5}^{\prime}$ end. This fragments was cloned into pOGH by using DNA fragments obtained by polymerase chain reaction (PCR) with introduced EcoRI and BamHI site at their ends. The oligonucleotide used as the $5^{\prime}$ primer of the $0.20 \mathrm{~kb}$ fragment is $5^{\prime}$ GGAATTCTCGCCGAGTGTCAG 3', which binds to -267 to -251 of the MAO A $5^{\prime}$ flanking sequence, at the $5^{\prime}$ end of the upstream 90 bp repeat (Fig. $1 B$ ). This primer will produce a cleavable EcoRI site at the $5^{\prime}$ end of their PCR product. The $3^{\prime}$ primer used is $5^{\prime}$ CCGGATCCTTCTATCAACTCCC 3 ', which binds to MAO A sequence -85 to -64 . This region contains the Drall site previously used as $3^{\prime}$ end of $\mathrm{A} 0.24$. Therefore, the $0.2 \mathrm{~kb}$ fragment produced will have the same $3^{\prime}$ end as $\mathrm{A} 0.24$ and have a cleavable BamHI site for cloning. The $5^{\prime}$ restriction enzyme site was changed to HindIII by cloning the EcoRI/BamHI fragment in pBSK (bluescript) and then isolating the fragment by HindIII + BamHI digestion. Promoter activity was assayed by measuring the human growth hormone secreted into medium by transfected SHSY -5Y (human neuroblastoma) cells as described previously (Zhu ct al., 1992).

Site-directed mutagenesis of Spl binding sites. The mutagenesis of the Spl binding sites in A0.24 was carried out with Amersham oligonucleotide-directed in vitro mutagenesis system (version 2.1). Oligonucleotides with desired mutation were annealed to single-stranded A0.24 fragment in M13, and a complementary strand was synthesized which incorporated the thionucleotide dCTP $\alpha$ S instead of normal dCTP. This substitution will protect the mutant strand from being nicked by NciI; therefore, only the wild-type strand was nicked. Exonuclease III was then used to digest part of the nonmutant strand, including the region to be mutated. The remaining part of the nonmutant strand was used as a primer to synthesize a complete double-stranded DNA with both strands mutated. In practice, however, mutagenesis experiments were difficult, possibly due to the repetitive structure of the A0.24 fragment. For example, the oligonucleotide designed to mutate $\mathrm{Sp} 12$ mutated both site 2 and 4 (site 2 CCCCGCCCA was mutated to CCCCGAACA and site 4 CCCCGCTCT to CCCCGAACT). The A0.14 fragment in which Spl site 2 was mutated was isolated from the A0.24 double mutant and cloned into pOGH in both orientations for promoter activity measurement. The mutated fragments was sequenced both in M13 and after their cloning into pOGH to ensure that the right mutations were achieved.

Nuclear extracts. Nuclear extracts from SHSY-5Y (human neuroblas- toma), NIH3T3 (mouse fibroblast) and Caco2 (human colon carcinoma) cells were prepared essentially according to published procedures (Dignam et al., 1983) except that the cells were ruptured in buffer $A$ in a polytron (Brinkman Homogenizer, model pcu 11) at position 3. $\mathrm{Mi}$ croscopic examination was performed to check cell breakage. The concentration of the nuclear proteins was determined by the bicinchoninic acid- $\mathrm{Cu}^{+}$method (Pierce), using BSA as standard. The extracts were stored in $0.1 \mathrm{ml}$ aliquots at $-80^{\circ} \mathrm{C}$ until use.

Gel retardation assay. The $0.24 \mathrm{~kb}$ Pvull/DraII fragment and 0.14 $\mathrm{kb}$ PvulI/DraII fragments werc cnd-labclcd with ${ }^{32} \mathrm{P}-\mathrm{dNTP}$ and Klenow large fragment of DNA polymerase. Five micrograms of poly[dI-dC][dI$\mathrm{dC}$ (Sigma) were preincubated with $1.6 \mu \mathrm{g}$ of nuclear protein or 30-60 $\mathrm{ng}$ of purified human Spl (Promega) for $10 \mathrm{~min}$ at room temperature in a mixture of $19 \mu$ l containing $20 \mathrm{~mm}$ HEPES-NaOH, pH $7.8,1 \mathrm{~mm}$ $\mathrm{MgCl}_{2}, 50 \mathrm{mM} \mathrm{NaCl}, 0.5 \mathrm{~mm}$ EDTA, $0.5 \mathrm{~mm}$ DTT, and $10 \%$ glycerol. One microliter of end-labeled DNA (about $2 \mathrm{fmol}$ ) was added, and incubation was continued for another $20 \mathrm{~min}$ at room temperature. After mixing with $2.5 \mu \mathrm{l}$ of loading buffer ( $250 \mathrm{~mm}$ Tris- $\mathrm{HCl}, \mathrm{pH} 7.8$, $0.2 \%$ xylene cyanol, $0.2 \%$ bromophenyl blue, $40 \%$ glycerol), the mixture was loaded on a $5 \%$ nondenaturing acrylamide gel (acrylamide : bisacrylamide $=37.5: 1$ ) in $90 \mathrm{~mm}$ Tris, $90 \mathrm{~mm}$ boric acid, $0.1 \mathrm{~mm}$ EDTA prerun at $10 \mathrm{~mA}$ for $1 \mathrm{hr}$. Gel electrophoresis was at $10 \mathrm{~mA}$ in the same buffer for the gel for $1.5 \mathrm{hr}$. The bands were visualized by autoradiography.

DNase I footprinting analysis. The $0.24 \mathrm{~kb}$ PvulI/DraII fragment, which contains all four $\mathrm{Spl}$ sites, the GA-rich sequence, and the TAATAA-containing sequence, was used for footprinting analysis. It was excised from their pOGH plasmids using the linker sites HindIII and $\mathrm{Xbal}$. The sense strand and the antisense strand of these two fragments were selectively labeled by using ${ }^{32} \mathrm{P}-\mathrm{dCTP}$ for the $3^{\prime} \mathrm{XbaI}$ site and ${ }^{32} \mathrm{P}$ dATP for the 5 ' HindIII site, respectively, in a fill-in reaction in the presence of a mutant Klenow large fragment of DNA polymerase that lacks exonuclease activity (Stratagene); $16.5 \mu \mathrm{g}$ of nuclear protein was first incubated with $5 \mu \mathrm{g}$ of poly[dA-dT][dA-dT] for $10 \mathrm{~min}$ at room temperature in $20 \mathrm{~mm}$ HEPES- $\mathrm{NaOH}$, pH $7.9,50 \mathrm{~mm} \mathrm{KCl}, 10 \mathrm{~mm}$ $\mathrm{MgCl}_{2}, 0.5 \mathrm{~mm}$ DTT, $0.5 \mathrm{~mm}$ EDTA, and $10 \%$ glycerol in a total volume of $19 \mu \mathrm{l}$. One microliter of labeled DNA (3-5 fmol) was added, and the mixture was incubated for another $20 \mathrm{~min}$ followed by DNase 1 digestion. The partial enzymatic cleavage was carried out at room temperature for 60 seconds. The amount of DNase 1 (Promega) used was determined empirically. The digestion was terminated by the addition of $5 \mu \mathrm{l}$ of $3 \mathrm{M}$ ammonium acetate and $0.1 \mathrm{M}$ EDTA; $125 \mu \mathrm{l} \mathrm{TE}$ buffer (10 mM Tris- $\mathrm{HCl}, \mathrm{pH} 8.0$ and $1 \mathrm{~mm}$ EDTA) was added, and the mixture was phenolized with $75 \mu \mathrm{l}$ of chloroform/phenol/isoamyl alcohol (24: $24: 1, \mathrm{v} / \mathrm{v} / \mathrm{v})$. The phenol phase was extracted with $50 \mu \mathrm{l}$ of TE. The two aqueous phases were combined and DNA was ethanol precipitated and washed twice with $-20^{\circ} \mathrm{C}, 70 \%$ ethanol. The pellet was dried in air and dissolved in $12 \mu \mathrm{l}$ of $5 \mathrm{~m}$ urea, $5 \mathrm{~mm}$ EDTA, $50 \%$ formamide, $0.3 \%$ xylene cyanol, and $0.3 \%$ bromophenyl blue. The samples were heated at $90^{\circ} \mathrm{C}$ for $2 \mathrm{~min}$, and then loaded immediately on a $7.5 \%$ acrylamide (acrylamide : bisacrylamide $=29: 1$ ), $8 \mathrm{M}$ urea gel. Both a short run and a long run were performed to examine the proximal (relative to the labeled end) and the distal part of the fragment. MspI-digested pBR322 fragments were end-labeled using ${ }^{32} \mathrm{P}$-dCTP and Klenow polymerase and were used as molecular weight standards. DNA bands were visualized by autoradiography.

$M A O A$ catalytic activity assay. MAO A activity was measured in a mixture containing $50 \mathrm{~mm}$ sodium phosphate buffer, $\mathrm{pH} 7.4$, cell homogenate and ${ }^{14} \mathrm{C}$ serotonin as previously described (Chen et al., 1984).

Northern analysis. Total RNA from SHSY-5Y, Caco2 cells and human placenta were isolated by guanidinium isothiocyanate extraction as described by Ausubel et al. (1989); $20 \mu \mathrm{g}$ of total RNA from SHSY$5 \mathrm{Y}$ and Caco 2 cells was fractionated on an agarose/formaldehyde gel and transfcrrcd to a nylon membrane (Bio-Rad), and then hybridized with ${ }^{32} \mathrm{P}$-labeled MAO A cDNA probe $\mathrm{A} 8$, which contains nucleotides 1-552 of MAO A cDNA (Bach et al., 1988). The membrane was washed at high stringency as described previously (Grimsby et al., 1990) and exposed for $3 \mathrm{~d}$. For detection of transcripts from upstream of MAO A core promoter, PolyA ${ }^{+}$RNA was isolated from the placenta and SHSY5Y total RNA with polyT columns supplied in the Micro-Fast Track mRNA Isolation Kit (version 1.2) from Invitrogen. A $1.2 \mathrm{~kb}$ PstI/PvuII fragment, immediately upstream of MAO A core promoter, was ${ }^{32} \mathrm{P}$ labeled and hybridized to the polyA + RNAs blotted on a nylon membrane as described above. 
A

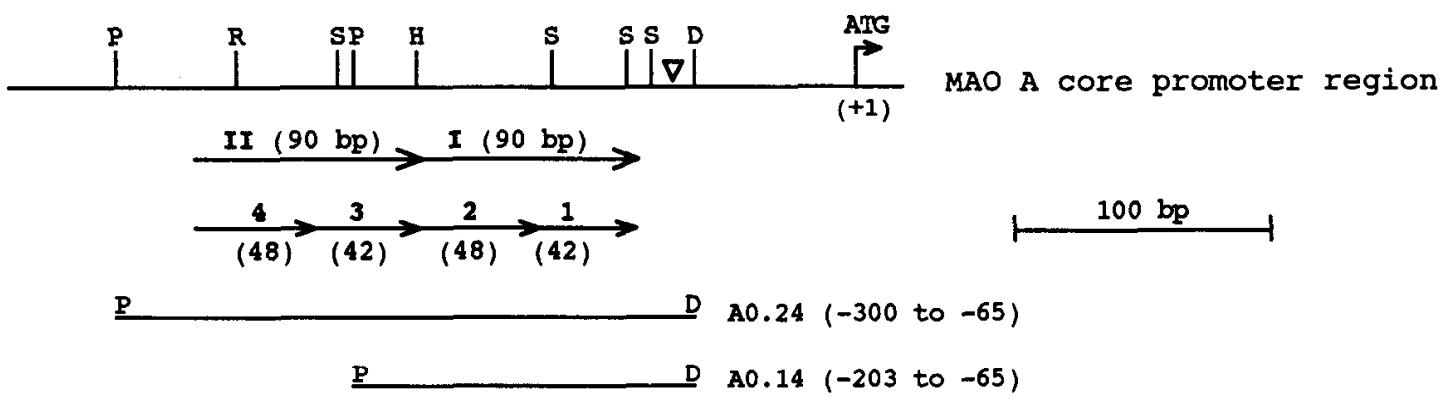

B

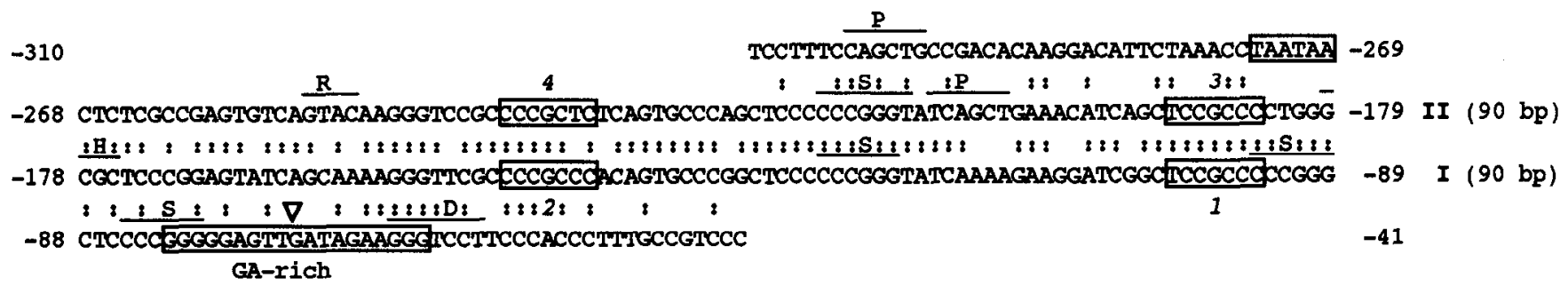

C

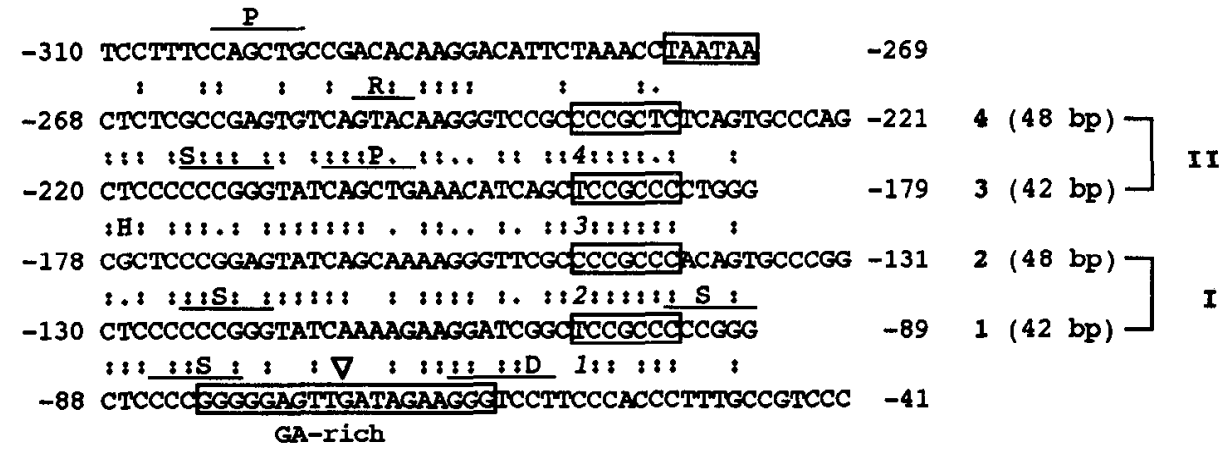

Figure 1. Direct repeats in MAO A core promoter region. $A$ is a restriction enzyme map of MAO A core promoter region; $A T G$ represents translation initiation codon. The location of the two $90 \mathrm{bp}$ repeats (repeats $I$ and $I I$ ) and the four shorter repeats (repeats $1,2,3$, and 4) are indicated by arrows. The positions of the MAO A $0.24 \mathrm{~kb}$ PvuIJ/DraII fragment (A0.24) and the $0.14 \mathrm{~kb}$ PvuII/Drall fragment (A0.14) are also shown. The location of the transcription initiation site mapped in human tissues is marked by a triangle (also in $B$ and $C$ ). The restriction enzyme sites are represented by a single letter: $D$, DraII; $H$, HinpI; $P$, PvuII; $R$, RsaI; $S$, Smal. $B$ shows sequence comparison of the two 90 bp repeats, which are from -268 to -179 and from -178 to -89 , respectively (the A of MAO A translation start codon ATG is defined as +1 ). The base pairs conserved between the two repeats are double dotted (:). The homology of the upstream (from -310 to -269 ) and the downstream (from -88 to -41 ) sequences with both repeats is also double dotted. The four $\mathrm{Spl}$ binding sites are boxed and numbered sequentially from $3^{\prime}$ to $5^{\prime}$ as in our previous report (Zhu et al., 1992). The upstream TAATAA sequence and the downstream GA-rich sequences are also boxed. Restriction enzyme sites are overlined and marked by single letters as in $A$. C shows repeats $1-4$, which are derived from the two 90 bp repeats I and II and numbered according to the number of the Sp1 site they contain. The base pairs conserved in at least three of the four repeats are double dotted. The single dots represent the conservation interrupted by a nonconserved base pair. For the upstream and downstream sequences, only the base pairs common to the conserved basepairs in repeats $1-4$ are marked. The $\mathrm{Sp} 1$ sites, the TAATAA sequence, the GA-rich sequence, and the restriction enzyme sites are marked as in $B$.

\section{Results}

The core promoter region of human MAO A gene is composed of four repeats, each containing an $S p 1$ binding site

Our previous work (Zhu et al., 1992) has shown that a MAO A promoter activity is located in two 90 bp repeats, which are contained in a $0.24 \mathrm{~kb}$ PvuIJ/DraII fragment (Fig. $1 A, B$; repeat $\mathrm{I}$ is from nucleotide -268 to -179 , and repeat II is from nucleotide -178 to -89 ; the A of the translation start codon ATG was defined as +1 ; the A0.24 fragment is from nucleotide -300 to -65$)$. There is $81 \%$ identity between these two repeats, and each repeat contains two potential $\mathrm{Sp} 1$ binding sites in the reversed orientation (Fig. $1 B$, boxed and sequentially numbered from $3^{\prime}$ to $5^{\prime}$ as sites 1,2 and 3, 4, respectively). These Sp1 sites have been shown to be essential for MAO A promoter activity (Zhu et al., 1992).

Further analysis of the two $90 \mathrm{bp}$ repeats showed that each repeat can be further divided into two repeats of 42 and $48 \mathrm{bp}$ in length, each containing an $\mathrm{Sp} 1$ site (Fig. $1 C$, repeats $1-4$ ). Thus, the two $90 \mathrm{bp}$ regions can be divided into four imperfect repeats, with the four $\mathrm{Sp} 1$ sites positioned at corresponding locations in each repeat.

As shown in Figure $1, B$ and $C$, the upstream $(-310$ to -269$)$ and downstream ( -88 to -41$)$ sequences showed certain degree of sequence homology with the two repeats. However, these sequences contain different potential cis-elements: instead of the $\mathrm{Sp} 1$ sites seen in repeats $1-4$, they contain a TAATAA sequence and a GA-rich sequence, respectively (also boxed). 
A
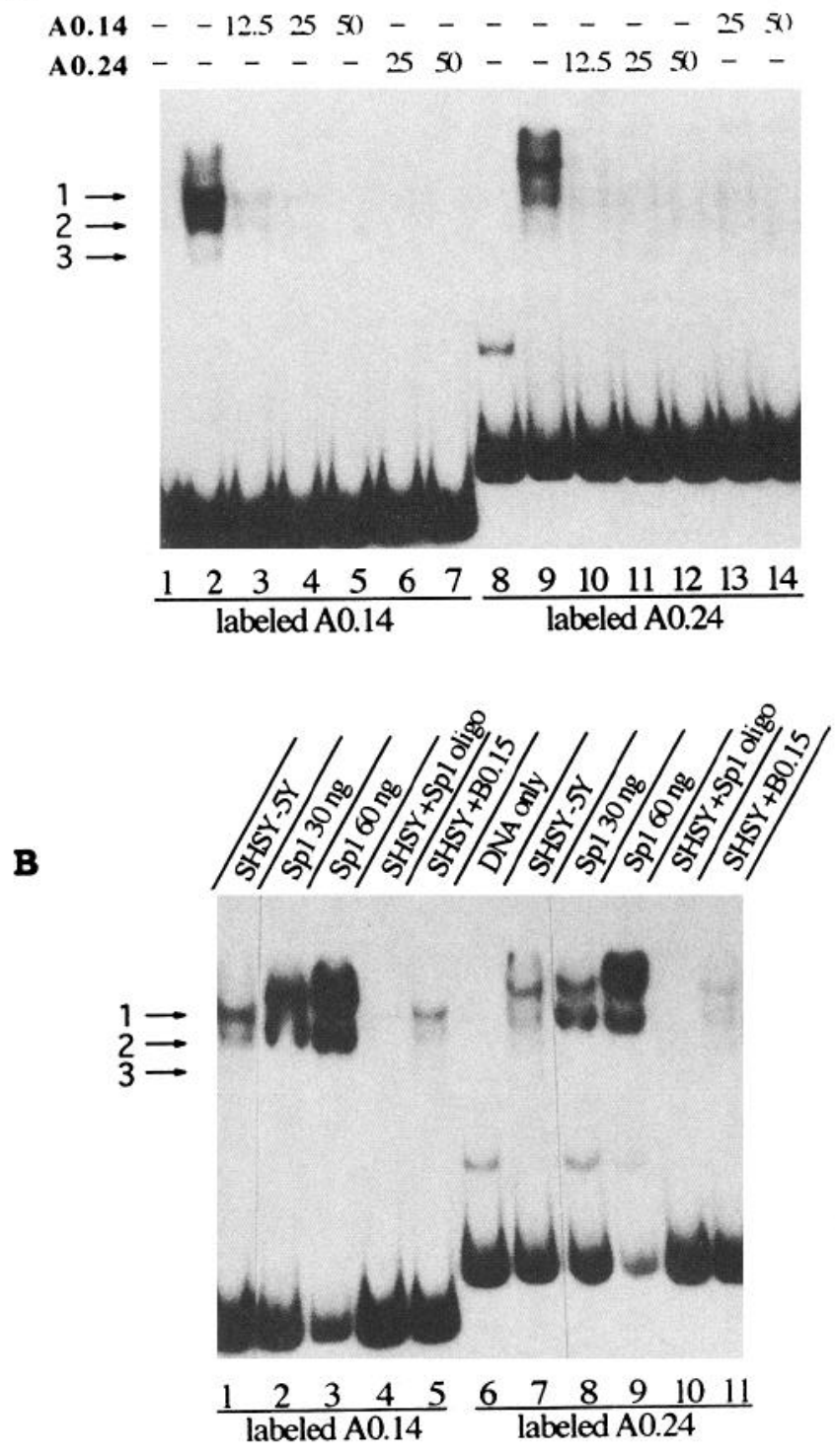

Figure 2. Gel retardation experiments showing Spl binding to MAO A core promoter fragments. $A$ shows the specificity of nuclear protein binding. The $0.14 \mathrm{~kb}$ PvuII/DraII fragment $(A 0.14)$ and the $0.24 \mathrm{~kb}$ PvuII/DraII fragment $(A 0.24)$ were ${ }^{32} \mathrm{P}$-end labeled and incubated with nuclear proteins under conditions described in Materials and Methods. Lanes 1 and 8 show free DNA of ${ }^{32} \mathrm{P}$-labeled A0.14 and A0.24 fragment, respectively, without addition of nuclear proteins. Lane 2, Nuclear proteins from SHSY -5Y cells were incubated with the labeled A0.14 fragment. The retarded bands are numbered. Lanes 3-7, The nuclear protein binding was competed with 12.5- (lane 3), 25- (lane 4), and 50- (lane 5) fold excess unlabeled A0.14 fragment and 25-(lane 6) and 50- (lane 7) fold excess of unlabeled A0.24 fragment. Lanes 9-14, Nuclear proteins from SHSY -5 Y cells were incubated with labeled A0.24 fragment then resolved on a polyacrylamide gel. In lane 9 , no specific competitive DNA was added. The nuclear protein binding was competed with $12.5-$ (lane 10), 25- (lane 11), and 50- (lane 12) fold excess unlabeled A0.24 fragment and 25-/(lane 13) and 50-(lane 14) fold excess unlabeled A0.14 fragment. $B$ demonstrates binding of $\mathrm{Sp} 1$ to the $\mathrm{A} 0.14$ (lanes $1-5$ ) and A0.24 (lanes 6-11) fragments. Lane 1 shows binding of SHSY-5Y nuclear proteins to the A0.14 fragment in the absence of specific competitive DNA. The retarded bands are numbered as in $A$. In lanes 2 and $3,30 \mathrm{ng}$ and $60 \mathrm{ng}$ purified Sp1 (Promega) instead of SHSY-5Y nuclear proteins were interacted with labeled A0.14 fragment. Lane 4, The binding of SHSY-5Y nuclear proteins to the labeled A0.14 fragment was competed with $0.5 \mathrm{pmol}$ of $\mathrm{Sp} 1$ consensus oligonucleotides. Lane 5 , The same binding was competed with 50 -fold excess of unlabeled
In a previous study (Zhu et al., 1992), we mapped multiple transcription initiation sites in a human neuroblastoma cell line (SHSY-5Y) that expresses high levels of MAO A mRNA. With the availability of more sensitive methods like $5^{\prime}$ RACE, we further investigated MAO A transcription initiation site in various human tissues. In this experiment, a polyC tail was added to the $3^{\prime}$ end of cDNA molecules with terminal transferase and PCR was performed using a primer for the $\mathrm{C}$ tail and nested primers specific for MAO A cDNA. With this method, we found that the MAO A initiation site was the same in all human tissues we tested, including frontal cortex, cerebellum, liver, intestine, and aorta smooth muscle, and was identical to the cDNA start site we published before (see Zhu et al., 1992, their Fig. 1, marked by an open arrow). This site was at -73 , downstream of all four Spl sites and right in the middle of the GA-rich sequence (Fig. $1 A-C$, marked by a triangle).

\section{$S p 1$ is the major transcription factor interacting with the $M A O$ A core promoter}

To identify the transcription factor(s) interacting with the MAO A core promoter, gel retardation and DNase 1 footprinting experiments were performed. Two end-labeled DNA fragments from MAO A core promoter region were used. One was the A0.24 fragment, which contains all four Spl sites and the flanking TAATAA and GA-rich sequences. The other was the A0.14 fragment, in which the TAATAA-containing sequence and Spl site 4 were deleted (Fig. 1). Since A0.14 shows the highest promoter activity in transfected cells, comparative study with A0.24 will demonstrate if there are any cis-elements in the extra sequence in A0.24 that may downregulate the promoter activity. Nuclear proteins were extracted from SHSY-5Y cells.

The gel retardation experiments shows that there are two strong (bands 1,2) and one weaker (band 3) retarded bands when A0.14 fragment was used (Fig. $2 A$, lane 2, bands marked by arrows). A concentration-dependent competition was observed in all three bands when 12.5- (lane 3), 25-(lane 4), and 50- (lane 5) fold excess unlabeled A0.14 DNA was used. The highest amount of the unlabeled A0.14 competitive DNA (50fold) was less than $1 \%$ of the nonspecific DNA (5 $\mu \mathrm{g}$ of poly[dI.dC][dI.dC]; see Materials and Methods), indicating that the three bands are specific to A0.14 fragment.

Similar results were observed with $\mathrm{A} 0.24$ fragment: two strong bands and a much weaker band were seen in gel retardation experiment (Fig. $2 A$, lane 9). Unlabeled A0.24 DNA competed efficiently (12.5-fold excess in lane 10, 25-fold in lane 11, and 50 -fold in lane 12), indicating that the binding is specific. Furthermore, A0.14 and A0.24 were good competitors for each other: 25- (lane 6) and 50- (lane 7) fold of A0.24 effectively removed the bands produced by labeled $\mathrm{A} 0.14$, and vice versa (Fig. $2 A$, lanes 13,14 ). These results suggest that the extra se-

$0.15 \mathrm{~kb}$ PstI/NaeI MAO B core promoter fragment (B0.15). Lane 6 shows the free DNA of labeled A0.24 fragment. Lane 7 shows binding of SHSY-5Y nuclear proteins to the labeled A0.24 fragment in the absence of specific competitive DNA. In lanes 8 and 9, $30 \mathrm{ng}$ and 60 ng purified Spl protein instead of SHSY-5Y nuclear proteins were included with the labeled A0.24 fragment, respectively. Lane 10, The binding of SHSY-5Y nuclear proteins to the labeled A0.24 fragment was competed with $0.5 \mathrm{pmol}$ of $\mathrm{Sp} 1$ consensus oligonucleotides. In lane 11 , the same binding was competed with 50 -fold excess of unlabeled B0.15 fragment mentioned above. 


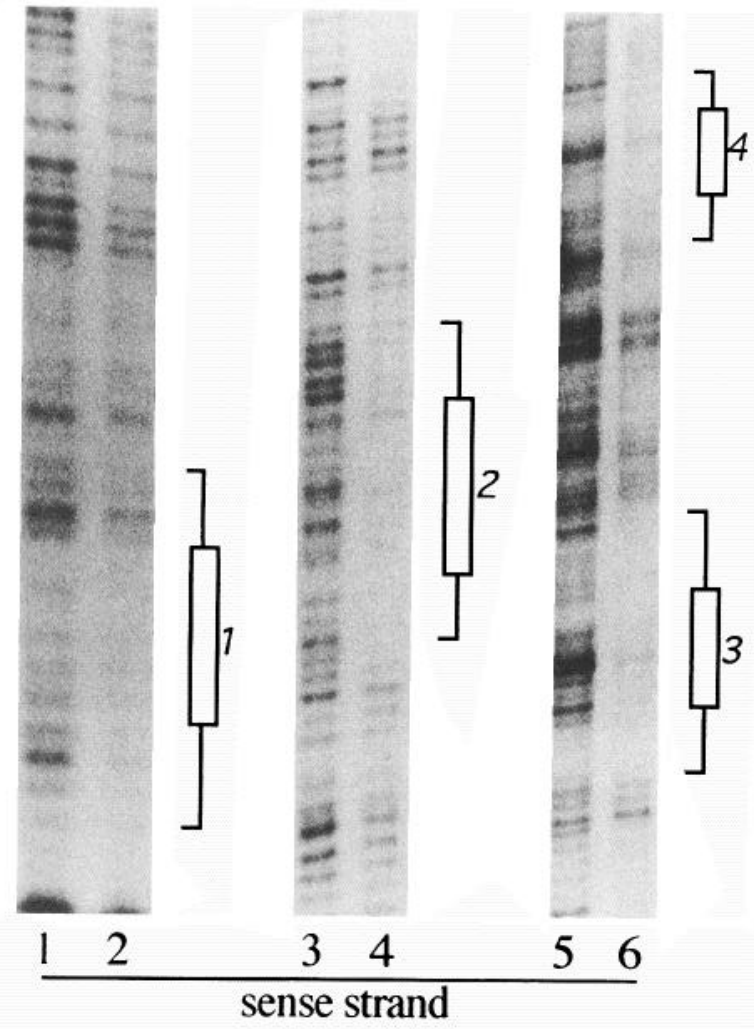

quence in A0.24 may not contain protein binding sites other than A0.14. On the other hand, MAO B $0.15 \mathrm{~kb}$ PstI/NaeI fragment (B0.15), which contains two clusters of overlapping Spl binding sites (Zhu et al., 1992), competed inefficiently with A0.14. Fifty-fold excess unlabeled B 0.15 only partially reduced the intensity of the three retarded bands with $\mathrm{A} 0.14$ (Fig. $2 B$, compare lanes 1 and 5) and with A0.24 (compare lanes 7 and 11), supporting the conclusion that the three retarded bands are specific for A0.14 fragment.

To investigate if the three retarded bands are Sp1-DNA complexes, synthetic Sp1 consensus oligonucleotides (Promega) and purified $\mathrm{Sp} 1$ protein were used in gel retardation experiments. Figure $2 B$ shows that $\mathrm{Spl}$ oligonucleotides completely abolished all three bands (lane 4 for A0.14 and lane 10 for A0.24, respectively), suggesting that these nuclear proteins are binding to $\mathrm{Sp} 1$ sequences. When $30 \mathrm{ng}$ (Fig. $2 \mathrm{~B}$, lane 2 for $\mathrm{A} 0.14$, lane 8 for A0.24) and $60 \mathrm{ng}$ (lane 3 for A0.14, lane 9 for A0.24) of purified $\mathrm{Spl}$ was used instead of nuclear protein extracts, the retarded bands were found at the same position as the two major bands (bands 1 and 2) given by SHSY-5Y nuclear proteins for A0.24 (Fig. $2 B$, compare lanes 2,3 with lane 1 and lanes 8,9 with lane 7). These results strongly suggest that the two heavy bands observed in Figure $2 A$, lanes 2 and 9 , and Figure $2 B$, lanes 1 and 7, are Sp1-DNA complexes. Since these two bands contained majority of DNA molecules in the retarded form, the transcription factor bound to the MAO A core promoter was mainly Sp1. The nature of the faster-moving weak band (Fig. $2 B$, band 3 in lane 1 and the corresponding band in lane 7) is not clear. It was sensitive to the competition of $\mathrm{Sp} 1$ consensus oligonucleotides but was not observed with purified Spl under our experiment conditions. It could still be an Sp1-DNA complex with less $\mathrm{Sp} 1$ sites bound than in bands 1 and 2 . In lanes 2 and 3 , due to relatively high concentration of Spl (compared with that in lane 1), more Sp1 sites were occupied, so the DNA molecules with less Spl sites occupied were in lower concentration and could not be seen on the autoradiograph. At the same time, this band may also represent another factor that interacts with $\mathrm{Sp} 1$ sites.

An extra DNA band with lower mobility was seen in the A0.24 DNA (Fig. $2 A$, lane $8 ; B$, lane 6), but not in A0.14 DNA (Fig. $2 A$, lane 1). Since no protein was added in these lanes, this extra band may be due to a nonlinear DNA structure formed by the repetitive sequences in A0.24 molecule.

The notion that $\mathrm{Sp} 1$ is the major transcription factor binding to MAO A core promoter was supported by DNase 1 protection (footprinting) experiments performed on both sense strand (Fig. 3 , lanes 1-6) and antisense strand (lanes 7-10) of the A0.24 DNA. The partial DNase 1 digestion patterns of each strand in the absence $(-$, lanes $1,3,5,7,9)$ and presence $(+$, lanes 2,4 , $6,8,10)$ of nuclear proteins are shown. Lane 2 shows protection of Spl site 1 in sense strand; lanes 4 and 8 show protection of Spl site 2 in sense and antisense strand, respectively; lanes 6 and 8 show protection of Spl site 3 in both strands and lanes 6 and 10 show that both strands of Spl site 4 were protected. No other protected regions could be identified unambiguously.

Cellular Spl concentration was associated with MAO A promoter activity and catalytic activity

When MAO A core promoter fragment was transiently transfected into different cell lines, different promoter activities were observed. For example, A0.14 exhibited much higher promoter activity in SHSY-5Y (human neuroblastoma) cells $(4356 \mathrm{cpm}$, $88 \%$ of the control metallothionein promoter) than in NIH3T3 (mouse fibroblast) cells $(332 \mathrm{cpm}, 2 \%$ of that of metallothionein promoter; Zhu et al., 1992). The significant difference in promoter activity in different cells could be caused by different 
$\mathbf{A}$

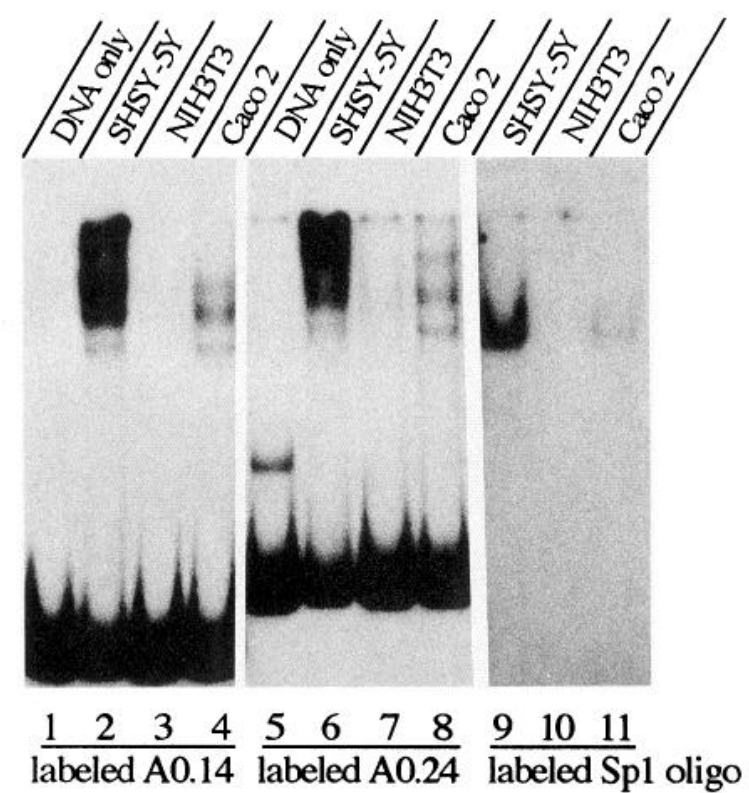

B

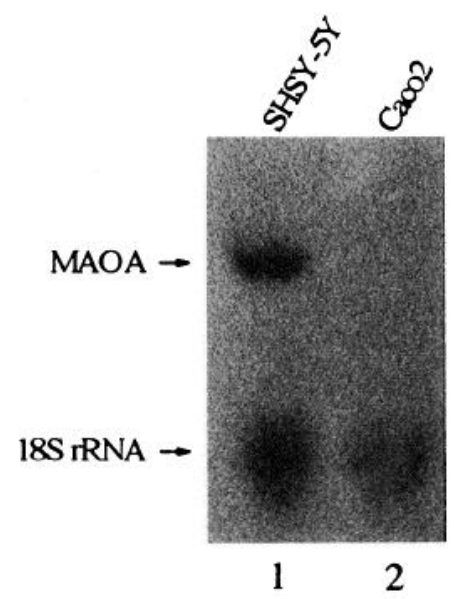

Figure 4. Sp1 and MAO A mRNA concentration in different cells. A, Comparison of Spl concentration in different cells-gel retardation assay. Lane 1 shows free DNA of ${ }^{32} \mathrm{P}$-end labeled A0.14 fragment. Same amount (1.6 $\mu \mathrm{g}$ of total protein) nuclear extracts from SHSY-5Y cells (lane 2), NIH3T3 cells (lane 3), and Caco2 cells (lane 4) was incubated with the labeled A0.14 fragment. Lane 5 shows free DNA of ${ }^{32} \mathrm{P}$-end labeled A0.24 fragment. Same amount (1.6 $\mu \mathrm{g}$ of total protein) of nuclear extracts from SHSY-5Y cells (lane 6), NIH3T3 cells (lane 7), and Caco 2 cell (lane 8) was incubated with the labeled A0.24 fragment. Lanes 911 show Sp1 concentration measured by $\mathrm{T} 4$ polynucleotide kinaselabeled Sp1 consensus oligonucleotides in $1.6 \mu \mathrm{g}$ of nuclear extracts from SHSY-5Y cells (lane 9), NIH3T3 cells (lane 10), and Caco2 cells (lane 11). B, Comparison of MAO A mRNA concentration in SHSY$5 \mathrm{Y}$ (lane 1) and $\mathrm{Caco} 2$ (lane 2) cells determined by Northern analysis as described in Materials and Methods. The blot was exposed for $3 \mathrm{~d}$ at $-80^{\circ} \mathrm{C}$ with an intensifying screen. $18 \mathrm{~S}$ rRNA was used as a control.

concentration of transcription factors, either activators or repressors, in different cells.

To study the effect of transcription factor concentration on MAO A promoter activity, nuclear extracts were made from SHSY-5Y and NIH3T3 cells and were used to perform gel retardation experiments with A0.14 fragment. When equal amounts of nuclear proteins from these cells were incubated with radiolabeled A0.14 fragment, the intensity of Spl binding in SHSY-5Y cells (Fig. 4A, lane 2) was much stronger than that in NIH3T3 cells (lane 3). This results suggests that the concentration of Spl is associated with the promoter activities of $\mathrm{A} 0.14$ measured in these two cell lines. No additional band was observed with NIH3T3 nuclear proteins, indicating that the lower promoter activity of A0.14 observed in NIH3T3 cells may not be due to the presence of an inhibiting transcription factor.

To study if the concentration of different transcription factors is associated with MAO A mRNA and catalytic activity, nuclear proteins were extracted from SHSY-5Y cells and Caco2 (human colon carcinoma) cells, which exhibit different MAO A catalytic activities (in SHSY-5Y cells, $3.36 \mathrm{nmol} / 20 \mathrm{~min} / \mathrm{mg}$ protein; in Caco 2 cells, $0.26 \mathrm{nmol} / 20 \mathrm{~min} / \mathrm{mg}$ protein). Northern analysis showed that MAO A mRNA level in SHSY-5Y cells (Fig. $4 B$, lane 1) was higher than in Caco2 cells (lane 2), indicating that MAO A regulation is mainly at the transcription level. Gel retardation showed that the intensity of Sp1 binding was higher in SHSY-5Y cells (Fig. 4A, lane 2) than in Caco2 cells (lane 4). These results again suggest that MAO A expression may be controlled by the concentration of Sp1. No additional band was seen with $\mathrm{Caco} 2$ nuclear proteins, indicating that the lower MAO A catalytic activity exhibited by this cell line may not be due to the presence of an inhibiting transcription factor.

In our previous article (Zhu et al., 1992), we reported that the mouse cell line NIH3T3 expresses very high MAO A catalytic activity $(15.59 \mathrm{nmol} / \mathrm{mg} / 20 \mathrm{~min})$ but showed very low promoter activity for transfected human MAO A promoter fragments (332 cpm for A0.14), suggesting that mouse MAO A promoter is different from human. Accordingly, the observed low Sp1 concentration in NIH3T3 cells, although associated nicely with the low promoter activity of transfected human MAO A promoter fragments, was not associated with mouse MAO A catalytic activity.

The same results were obtained with A0.24 fragment (Fig. $4 A$, lanes $5-8$ ). The intensity of the $\mathrm{Sp} 1$ bands was stronger in SHSY-5Y cells (lane 6) than in NIH3T3 cells (lane 7), which is associated with higher promoter activity of $\mathrm{A} 0.24$ fragment measured in SHSY-5Y cells $(2318 \mathrm{cpm})$ than in NIH3T3 cells $(286 \mathrm{cpm})$. The stronger Sp1 bands observed in SHSY-5Y cells (lane 6) than in $\mathrm{Caco} 2$ cells (lane 8) are also associated with the higher MAO A mRNA level and catalytic activity in SHSY-5Y cells than in Caco2 cells.

Furthermore, the concentration of Sp1 in these cell lines was measured by using radiolabeled $\mathrm{Sp} 1$ consensus oligonucleotides (lanes 9-11). The intensity of the Sp1-DNA complex was the highest with SHSY-5Y nuclear proteins (lane 9) compared with that with NIH3T3 (lane 10) and Caco2 (lane 11) nuclear proteins. These results indicate that the intensity of the $\mathrm{Sp} 1$ bands indeed represents $\mathrm{Spl}$ concentration in these cells.

These results show clearly that there is a positive association between Sp1 concentration and MAO A promoter and catalytic activity. Thus, cellular $\mathrm{Sp} 1$ concentration seems to be an important controlling factor for MAO A expression.

\section{MAO A core promoter exhibited bidirectional promoter activities that were differentially controlled by four Sp1 sites}

The A0.24 fragment, which contains four Sp1 binding sites, was found to exhibit promoter activity in both orientations. To define the role of each cis-element (the four Sp1 binding sites and GA-rich and TAATAA-containing sequences; see Fig. 1 for the sequences) in promoter activities in two opposite directions, serial $5^{\prime}$ and $3^{\prime}$ deletions were made for the A0.24 fragment (Fig. 


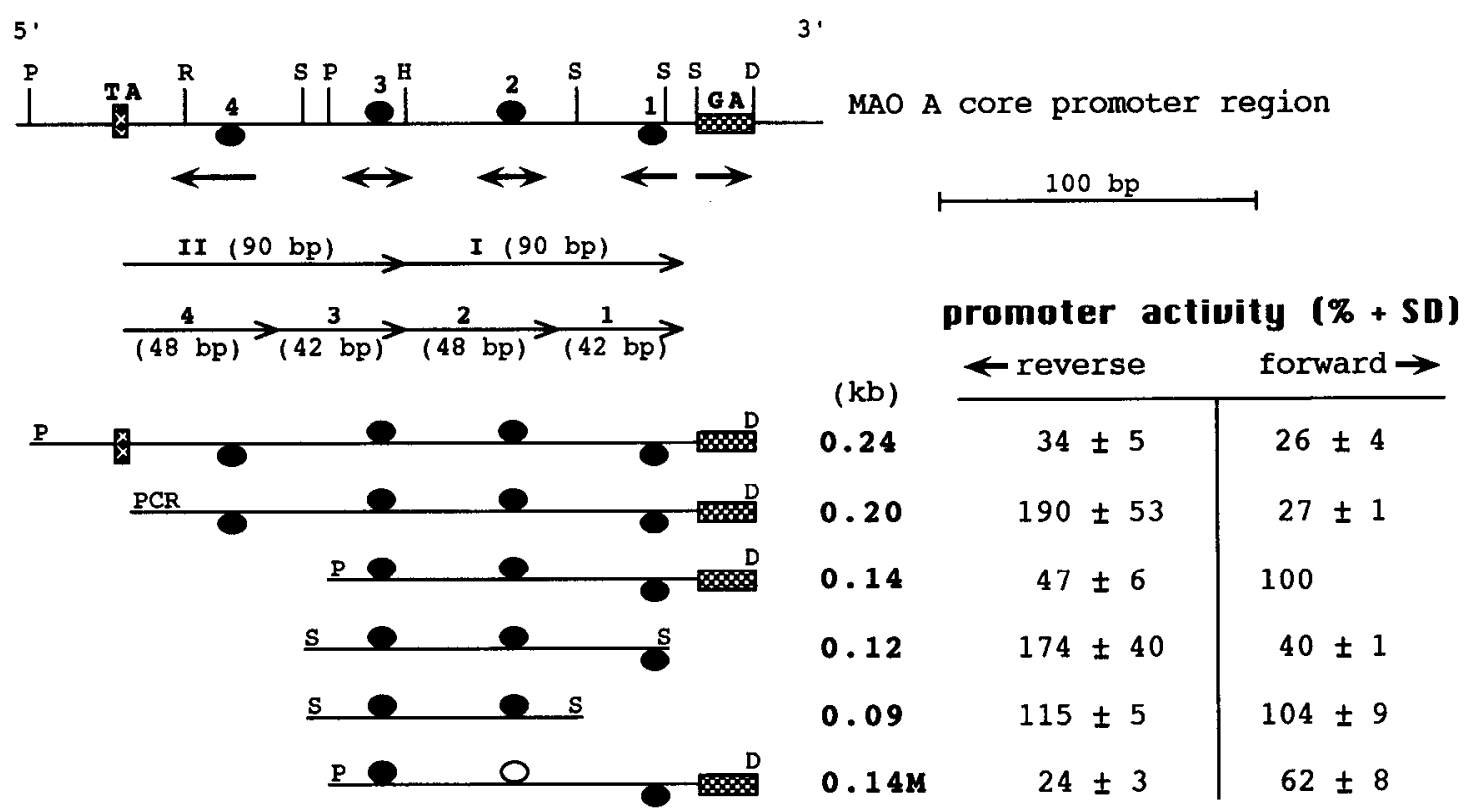

Figure 5. Bidirectional promoter activity of the MAO A core promoter. At the top is the restriction map of the $0.24 \mathrm{~kb}$ PvuII/DraII core promoter fragment similar to the shown in Figure 1. The restriction enzyme sites are marked by a single letter as in Figure 1. Ovals represent the location of the four Sp1 sites (numbered sequentially from $3^{\prime}$ to $5^{\prime}$ ): Spl sites 2 and 3 are on the same side of the DNA while Sp1 sites 1 and 4 are on the other side of the DNA (see text for explanations). The open oval represents a mutated Spl site. The TAATAA sequence (TA) is shown by the crosshatched box and the GA-rich sequences $(G A)$ are shown by checkered boxes. The positions of the two 90 bp repeats $(I$ and $I I)$ and the four shorter repeats of 48 and $42 \mathrm{bp}$ in length $(1-4)$ are indicated by thin arrows below the map. The direction of thick arrow under its corresponding cis-element [Spl sites $1-4$ and the GA-rich $(G A)$ sequences] indicates the favorable transcription direction of the element. The forward arrow under the element $G A$ means the element favors the forward promoter activity; the rearward arrows under Spl sites 1 and 4 mean these elements favor the reverse promoter activity. The double-headed arrows under Sp1 sites 2 and 3 indicate that these two sites promote both forward and reverse transcription. The sizes of the DNA fragments $(\mathrm{kb})$ used in promoter activity measurements are shown at their $3^{\prime}$ end. Fragment $0.14 M$ (the fragment at the bottom) is the same as fragment 0.14 except that Spl site 2 was mutated from CCCGCCC to CCCGAAC. The symbol PCR at the $5^{\prime}$ end of fragment 0.20 indicates that the $5^{\prime}$ end of this fragment was produced by PCR. The forward and the reverse promoter activity are expressed as percentage of the forward promoter activity of the fragment 0.14 , which is defined as $100 \%$, with SD given.

5). Each fragment was then linked, in both orientations, to the human growth hormone reporter gene in promoterless vector pOGH and pOGHR (see Materials and Methods). These constructs were transfected into SHSY-5Y cells. The activities measured in both orientations were presented as the percentage of the forward activity of A0.14 fragment, which was defined as $100 \%$.

As shown in Figure 5, the A0.24 fragment exhibited similar promoter activity in both orientations $(26 \%$ and $34 \%$ activity for forward and reverse activity, respectively). A 5' deletion that removed the TAATAA-containing sequences $5^{\prime}$ of the two 90 bp repeats (construct 0.20 ) had little effect on the forward promoter activity (from $26 \%$ to $27 \%$ ), but increascd significantly the reverse promoter activity (from $34 \%$ to $190 \%$ ), suggesting that the TAATAA-containing sequence inhibits the reverse activity. Further deletion of Spl site 4 increased the forward activity about four times (from $27 \%$ to $100 \%$; see fragments 0.20 and 0.14 ) but decreased the reversed activity about fourfold (from $190 \%$ to $47 \%$ ), indicating that site 4 is important for the reverse activity but downregulates the forward activity.

A 3' deletion that removed the GA-rich sequence $3^{\prime}$ of the two $90 \mathrm{bp}$ repeats decreased forward activity of A0.14 to $40 \%$ (compare fragments 0.12 and 0.14 ), but increased the reverse activity by more than threefold (from $47 \%$ to $174 \%$ ), suggesting that the GA-rich sequence enhanced transcription toward the forward direction but inhibited the reverse promoter activity. Since the transcription initiation site mapped with $5^{\prime}$ RACE is located at the center of this sequence, it is possible that this sequence enhances transcription and at the same positions initiation site, like the reported transcription element Initiator (Smale and Baltimore, 1989) and HIP1 (Means and Farnham, 1990). Further removal of Sp1 site 1 from fragment 0.12 doubled the forward activity (from $40 \%$ to $104 \%$; see fragments 0.12 and 0.09 ), but decreased the reverse activity significantly (from $174 \%$ to $115 \%$ ).

Mutation of site 2 from CCCGCCC to CCCGAAC decreased both the forward activity (from 100\% to 62\%; compare fragments 0.14 and $0.14 \mathrm{M}$ ) and the reverse activity (from $47 \%$ to $24 \%$ ) of the A0.14 fragment, indicating that Spl site 2 promotes transcription in both orientations. Spl sites 2 and 3 contained in a $90 \mathrm{bp} \mathrm{SmaI/SmaI} \mathrm{fragment} \mathrm{(0.09)} \mathrm{promoted} \mathrm{transcription}$ in both orientations with approximately equal efficiency $(115 \%$ and $104 \%$ for the reverse and forward activity, respectively).

These results are summarized with thick arrows under each cis-element in the restriction enzyme map in Figure 5. The two central Sp1 sites (2 and 3) drive transcription in both orientations with similar efficiency. The forward activity, which is for the expression of the MAO A gene, is downregulated by Spl sites 1 and 4, but is enhanced by the GA-rich sequence proximal to the MAO A gene. Their reverse promoter activity, which might drive expression of an unidentified gene, is increased by Spl sites 1 and 4, but downregulated by the GA-rich sequence at the $3^{\prime}$ end and the TAATAA-containing sequence at the 5' end. Thus, the promoter activity of Sp1 sites 2 and 3 for each orientation has its own means for positive and negative regulation. The balanced effects of all these elements are the nearly 
$\mathbf{A}$

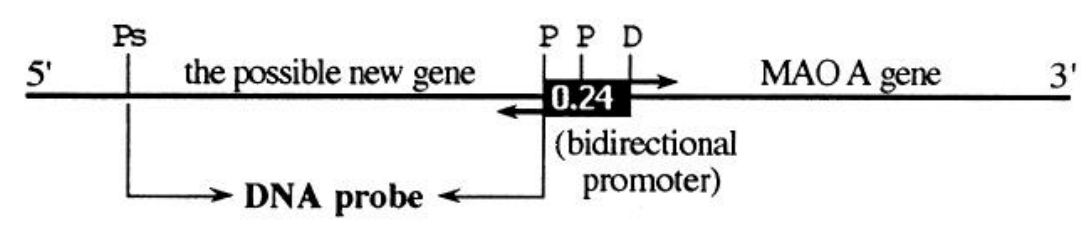

Figure 6. Northern analysis showing that the sequence upstream of MAO core promoter is expressed. $A$ shows that two genes, the MAO A gene and a possible new gene, are transcribed by the bidirectional MAO A core promoter (the box labeled 0.24). The opposite arrows from the core promoter represent the opposite promoter activities. A $1.2 \mathrm{~kb}$ PstI $(P S) /$ PvuII $(P)$ fragment $5^{\prime}$ of the core promoter was used as a DNA probe to detect the reverse transcripts. $B$, Northern analysis. PolyA + RNA from SHSY-5Y (lane 1) and human placenta (lane 2) cells was hybridized with the ${ }^{32} \mathrm{P}$-labeled DNA probe shown in $A$. The $10 \mathrm{~kb}, 6 \mathrm{~kb}$, and $3 \mathrm{~kb}$ bands in placenta RNA are marked. The residue $28 \mathrm{~S}$ and $18 \mathrm{~S}$ rRNAs in both RNA samples are also indicated. The blot was exposed for $20 \mathrm{~d}$ at $-80^{\circ} \mathrm{C}$ with an intensifying screen.

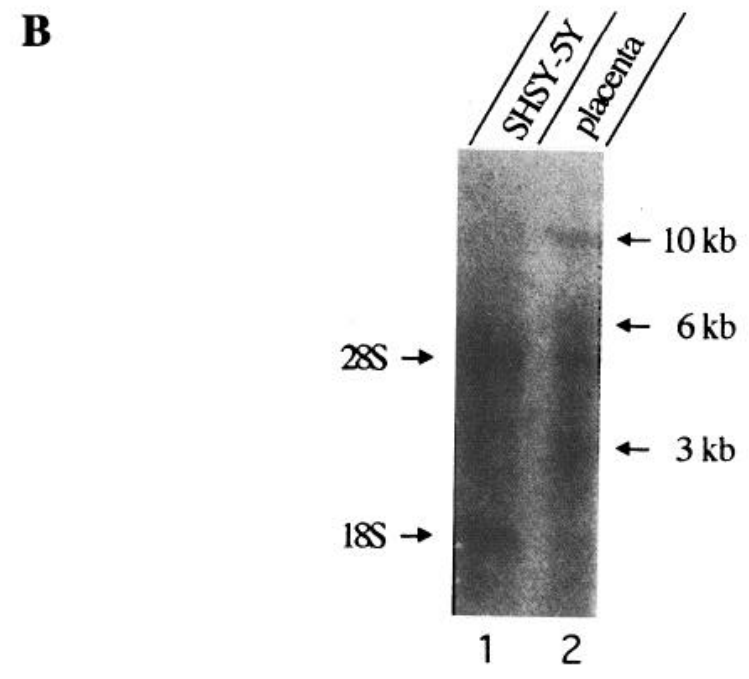

equal forward (26\%) and reverse (34\%) promoter activities by fragment A0.24, which contains all these elements.

Transient transfection assay in SHSY-5Y and NIH3T3 cells showed that the reverse promoter activity of the A0.14 fragment was higher in SHSY $-5 Y$ cells $(688 \mathrm{cpm}, 14 \%$ of the control metallothionein promoter) than in NIH3T3 cells $(58 \mathrm{cpm}, 1 \%$ of the control metallothionein promoter). Thus, the reverse promoter activity is also dependent on the concentration of Spl.

The sequence upstream of MAO A core promoter was expressed endogenously

To study the possible physiological significance of the reverse promoter activity, a $1.2 \mathrm{~kb}$ PstI/PvuII fragment, immediately $5^{\prime}$ of the core promoter $(0.24 \mathrm{~kb}$ PvuII/DraII fragment; see Fig. $6 \mathrm{~A}$ ), was isolated, ${ }^{32} \mathrm{P}$-labeled, and hybridized to a human Northern blot. Positive signals were seen in placenta RNA (not shown). Since our probe also hybridized with ribosome RNAs, to get a clearer picture, polyA ${ }^{+}$RNA from placenta and SHSY $-5 Y$ cells were used. Figure $6 B$ shows three bands of 3,6 , and $10 \mathrm{~kb}$ in placenta polyA + RNA (lane 2), but not in SHSY-5Y RNA (lane 1). These bands demonstrate that the DNA sequence upstream of MAO A core promoter is expressed endogenously. Very likely these upstream transcripts were from the other strand of DNA (relative to MAO A transcripts) by the reverse promoter activity of MAO A core promoter. In other words, MAO A core promoter may endogenously transcribe a new gene upstream of MAO A.

\section{Discussion}

This report describes our further studies on human MAO A core promoter and provides a number of interesting new results. The structure of MAO A core promoter is highly organized.

Previously we reported that it is composed of two 90 bp repeats, each containing two Spl binding sites (Zhu et al., 1992). It is interesting that the core promoter sequences can be further divided into four imperfect repeats, each containing a Sp1 site at corresponding position. In addition, the sequence $3^{\prime}$ of the four repeats, from nucleotide -88 to -52 (the $3^{\prime} \mathrm{C}$ of the sequence CCCACCC; see Fig. $1 C$ ), exhibits lower but still significant sequence homology with the four repeats. Due to these repeating sequences, the boundary of the two $90 \mathrm{bp}$ repeats is somewhat arbitrary. In fact, the two 90 bp repeats shown in this report are shifted to the $5^{\prime}$ direction by $9 \mathrm{bp}$ from the ones we published previously in order to coincide with the five shorter repeats presented in this report. The base pair -268 seems to be the $5^{\prime}$ limit of the repeating structure; from here down, any segment of DNA will be homologous to the DNA segment $90 \mathrm{bp}$ downstream, until the $3^{\prime}$ limit at -52 is reached.

With the more sensitive $5^{\prime}$ RACE techniques, we have investigated MAO A transcription initiation sites in various human tissues. The transcription initiation site was found at -73 and was the same as the cDNA start sites in all human tissues tested. This initiation site is downstream of the Spl binding sequences in MAO A core promoter and seems to be the initiation site for the promoter we detected in the two 90 bp repeat region. The upstream initiation sites we mapped in SHSY-5Y cells with primer extension experiments may be derived from an upstream CCAAT-TATA type promoter that operates only under certain conditions, as we suggested previously (Zhu et al., 1992). In that experiment, the -73 initiation site was in the low-molecular-weight region, thus could not be seen clearly.

With similar anchor-PCR techniques, Denney's group mapped multiple initiation sites between -30 and -140 in human brain and colon tumor cells, with the major initiation sites between 
-30 and -40 (Denney et al., 1993). Thus, the initiation sites mapped by the two laboratories with similar techniques are in the same broad region at the $3^{\prime}$ end of MAO A core promoter, supporting the key role of the $\mathrm{Sp} 1$ sites in the core promoter for MAO A expression.

Sequence homology data show that the similarity between the two $90 \mathrm{bp}$ repeats $(81 \%)$ is higher than that between the four shorter repeats $(74 \%$ if the residues present in at least three of the four repeats are considered conserved; $50 \%$ if the residues present in all four repeats are considered conserved; the extra $6 \mathrm{bp}$ in the 48 repeats were not included in homology calculation). It is tempting to postulate that the present MAO A core promoter was formed by a recent duplication of a $90 \mathrm{bp}$ segment in the prototype of MAO A promoter. Such duplication increased the number of $\mathrm{Sp} 1$ sites in the promoter, thus rendering the present promoter more resistant to the effect of mutational destruction of its $\mathrm{Sp} 1$ sites. This redundant structure of the MAO A core promoter implies that MAO A expression may not be easily abolished completely by a few point mutations in the promoter. Therefore, complete loss of MAO A catalytic activity may be caused by mutations or deletions of the coding sequences, such as a point mutation resulted in the premature termination of MAO A protein found in the Dutch kindred (Brunner et al., 1993b).

The four $\mathrm{Spl}$ sites created by duplication process are arranged in special ways: the central two $\mathrm{Sp} 1$ sites (sites 2 and 3) are 42 bp apart, so they are on the same side of the DNA (each turn of B-DNA contains $10.5 \mathrm{bp}$; Wang, 1979) and the two flanking Spl sites (sites 1 and 4) are 48 bp from site 2 or 3 ; thus, they are on the other side of the DNA (see Fig. 5). These special arrangements, together with other cis-elements (like the $3^{\prime}$ GArich and 5' TAATAA-containing sequences), provide additional means for regulation, which is demonstrated in deletion analysis shown in Figure 5. Therefore, different levels of MAO A expression may be caused by the alteration of the promoter sequence, or the change of concentration of the relevant transcription factor $(\mathrm{Sp} 1)$ in the cells.

The following cvidence obtaincd from gel retardation, DNase 1 footprinting experiments, and promoter activity measurements strongly suggests that $\mathrm{Spl}$ is the major transcription factor interacting with MAO A core promoter: (1) the binding of nuclear proteins to MAO A promoter fragments was effectively competed by $\mathrm{Spl}$ consensus oligonucleotides, (2) only the Spl sites were clearly protected from DNase 1 digestion, (3) purified Spl gave identical retarded bands as nuclear proteins, (4) the promoter activity of the A0.14 (or A0.24) fragment, MAO A mRNA level, and catalytic activity are associated with the cellular concentration of Spl (also see below).

It has been reported that several other transcription factors also bind to $\mathrm{Spl}$ sites. However, these transcription factors can be excluded to be the binding factor in our experiments. For example, AP-2 consensus oligonucleotides did not compete with the labeled A0.14 or A0.24 fragment (figure not shown), indicating that the binding factor is not AP-2. In addition, AP-2 has a molecular weight of $52 \mathrm{kDa}$ (Mitchell et al., 1987), different from that of Sp1 (95 and $105 \mathrm{kDa}$; Michael et al., 1986). If AP-2 were the binding factor, then the mobility of the retarded bands would be different from Spl-DNA complexes we observed. The same reasoning can be used to exclude ETF (120 kDa; Kageyama et al., 1988), EGR-1 (80 kDa; Cao et al., 1990), EGR-2 (43 kDa; Joseph et al., 1988), and WT1 (49-51 kDa; Telerman et al., 1992). Furthermore, AP2, ETF, and EGR-1 are induced by phorbol esters, but the activity of MAO A fragments from the core promoter region was not (data not shown). The molecular weight of GCF (100 kDa; Kageyama and Pastan, 1989 ) is very similar to $\mathrm{Sp} 1$. However, the observed positive association between MAO activity and the amount of bound nuclear proteins in gel retardation experiments may argue against GCF to be the major bound species, because GCF has been shown to be a negative regulator. On the other hand, the present report does not rule out the possibility that other transcription factors may bind to these $\mathrm{Spl}$ sites in MAO A core promoter and give the same binding patterns as $\mathrm{Sp} 1$, so are indistinguishable in gel retardation and footprinting experiments. Since we have tested only a limited number of cell lines, the possibility cannot be excluded that in other cells or tissues, different transcription factors may interact with MAO A core promoter and regulate MAO A expression. The sequences outside of the core promoter may also play a role. Nonetheless, in the cell lines we so far studied, Spl seems to be the major transcription factor interacting with MAO A core promoter.

$\mathrm{Spl}$ is a general transcription factor found in all cells of higher animals and is required for GC box containing promoters. Since many housekeeping gene promoters are $\mathrm{GC}$ rich and contain Spl binding sites, the existence of Spl should be universal. On the other hand, Spl concentrations changes dramatically (as high as 100-fold) from tissue to tissue and during development (Saffer et al., 1991), suggesting that $\mathrm{Spl}$ has a regulatory role. In other words, Spl might be a limiting factor for many promoters. This hypothesis is supported by the elevated transcription of Sp1-depending genes when cellular Sp1 concentration becomes higher (Saffer et al., 1990). The positive association between cellular $\mathrm{Sp} 1$ concentration and MAO A promoter activity (both forward and reverse), mRNA level, and catalytic activity we observed in cultured cell also suggests that cellular Spl concentration is an important controlling factor for the expression of human MAO A gene. It will be interesting to investigate further whether the different MAO A catalytic activities in different tissues, developmental stages, and diseased statcs are also regulated by $\mathrm{Sp} 1$ concentration.

Our transient transfection assays demonstrate that the MAO A core promoter has bidirectional activities. Promoters functioning in both orientations are found initially in microorganisms and mitochondrial DNA. In recent years, bidirectional promoters in higher eukaryotic organisms have been reported. Some of these bidirectional promoters are housekeeping genes and contain Spl binding sites, such as the promoters of mouse dihydrofolate reductase (dhfr) gene, mouse thymidine kinase (TK) gene (Weichselbraun et al., 1990), and human hypoxanthine phosphoribosyl transferase (HPRT) gene (Johnson and Friedman, 1990). However, bidirectional promoter is not limited to the Spl type. In mouse heavy chain immunoglobin promoter VH441, the bidirectional transcription is driven by a octomer element (ATGCAAAT) and controlled by a TATAlike element at each side of the element (Nguyen et al., 1991). For some of such bidirectional promoters, in addition to their "normal" transcripts, the endogenous reverse transcripts have also been detected, like the mouse heavy chain immunoglobin promoter VH441 (Nguyen et al., 1991), murine $\alpha-1$ and-2 (IV) collagen transcripts (Burbello et al., 1988), human proliferating cell nuclear antigen (PCNA) gene promoter (Rizzo et al., 1990), chicken skeletal $\alpha$-actin gene promoter (Grichnik et al., 1988), mouse HTF9 housekeeping promoter (Somma et al., 1991), and the most intensively studied dihydrofolate reductase promoter 
(Crouse et al., 1985; Farnham et al., 1985; Linton et al., 1989; Shimada et al., 1989; Smith et al., 1990; Ciudad et al., 1992; Fujii et al., 1992). The increasing list of physiologically functional eukaryotic bidirectional promoters indicates that promoters transcribing both strands of DNA really work in higher animals, including human being. The difficulties in detecting some reverse transcripts at least in some cases can be due to the fast turnover of these transcripts (Grichnik et al., 1988), or the reverse activity works only under special circumstances. On the other hand, the bidirectional promoters are often detected with isolated DNA fragments; thus, the DNA elements and endogenous promoter environments that prevent the reverse transcription (which may not always be beneficial) in the cells may be lost, so the reverse promoter activity detected in transfection assay may not function similarly in the intact genome in the cells. For example, human HPRT promoter exhibits bidirectional promoter activities in transfection assay, but no endogenous reverse promoter activity has been detected (Johnson and Friedman, 1990).

Our data show that the sequence upstream of MAO A core promoter is expressed endogenously, implying that the bidirectional promoter activities exhibited by the core promoter might transcribe another gene in addition to MAO A. So far, the upstream transcripts have been detected in placenta only, suggesting that there may be mechanisms controlling the relative expression level of the two genes. Thus, in addition to the role of $\mathrm{Sp} 1$ in MAO A expression, the study on how the two opposite promoter activities are regulated might provide further insight for the mechanism of MAO A regulation.

\section{References}

Ausubel FM, Brent R, Kingston RE, Moore DD, Seidman JG, Smith JA, Struhl K, eds (1989) Current protocols in molecular biology, pp 4.2.1-4.2.5. New York: Wiley.

Bach AWJ, Lan NC, Johnson DL, Abell CW, Bembenek ME, Kwan S-W, Seeberg PH, Shih JC (1988) cDNA cloning of human monoamine oxidase $A$ and $B$ : molecular basis of differences in enzymatic properties. Proc Natl Acad Sci USA 85:4934-4938.

Brunner HG, Nelen MR, van Zandvoort P, Abeling NGGM, van Gennip AH, Wolters EC, Kuiper MA, Ropers HH, van Oost BA (1993a) $\mathrm{X}$-linked borderline mental retardation with prominent bchavioral disturbance: phenotype, genetic localization, and evidence for disturbed monoamine oxidase metabolism. Am J Hum Genet 52:10321039.

Brunner HG, Nelen M, Breakefield XO, Ropers HH, van Oost BA (1993b) Abnormal behavior associated with a point mutation in the structural gene for monoamine oxidase A. Science 262:578-580.

Burbelo PD, Martin GR, Yamada Y (1988) Alpha 1 (IV) and alpha 2 (IV) collagen genes are regulated by a bidirectional promoter and a shared enhancer. Proc Natl Acad Sci USA 85:9679-9682.

Cao X, Koski RA, Gashler A, McKieman M, Morris CF, Gaffney R, Hay RV, Sukhatme VP (1990) Identification and characterization of the EGR-1 gene product, a DNA binding zinc finger protein induced by differentiation and growth signals. Mol Cell Biol 10:1931-1939.

Chen K, Wu HF, Shih JC (1993) The deduced amino acid sequences of human platelet and frontal cortex monoamine oxidase $B$ are identical. J Neurochem 61:187-190.

Chen S, Shih JC, Xu QP (1984) Interaction of $N$-(2-nitro-4-azidophenyl)-serotonin with two types of monoamine oxidase in rat brain. J Neurochem 43:1680-1687.

Chiba K, Trevor A, Castagnoli N (1984) Metabolism of the neurotoxic tertiary amine, MPTP by brain monoamine oxidase. Biochem Biophys Res Commun 120:574-578.

Ciudad CJ, Morris AE, Jeng C, Chasin LA (1992) Point mutation analysis of the hamster dihydrofolate reductase minimum promoter. J Biol Chem 267:3650-3656.

Crouse GF, Leys EJ, McEwan RN, Frayne EG, Kellems RE (1985)
Analysis of the mouse dhfr promoter region: existence of a divergently transcribed gene. Mol Cell Biol 5:1847-1858.

Denney RM, Dave SK, Waguespack A (1993) Identification of likely transcription initiation sites for the human MAO A gene: new evidence from PCR-assisted primer extension and RNase protection assays. Slide presentation at the 23 rd annual meeting of Society for Ncuroscicnce, Washington, DC, November.

Dignam JD, Lebovites RM, Roeder RG (1983) Accurate transcription initiation by RNA polymerase II in a soluble extract from isolated mammalian nuclei. Nucleic Acids Res 11:1475-1489.

Donnelly CH, Murphy DL (1977) Substrate- and inhibitor-related characteristics of human platelet monoamine oxidase. Biochem Pharmacol 26:853-858.

Egashira T, Yamanaka Y (1981) Further studies on the synthesis of A-form of MAO. Jpn J Pharmacol 31:763-770.

Farnham PJ, Abrams JM, Schimke RT (1985) Opposite-strand RNAs from the $5^{\prime}$ flanking region of the mouse dihydrofolate reductase gene. Proc Natl Acad Sci USA 82:3978-3982.

Fowler JB, Macgregor RR, Wolf AP, Arnett CD, Dewey SL, Schlyer D, Christman D, Logan J, Smith M, Sachs H, Aquilonius SM, Bjjurling $P$, Halldin C, Hartvig P, Lecnders KL, Lundqvist H, Oreland L, Stalnacke C-G, Langstrom B (1987) Mapping human brain monoamine oxidase $\mathrm{A}$ and $\mathrm{B}$ with " $\mathrm{C}$-labelled suicide inactivators and PET. Science 235:481-485.

Fritz RR, Abell CW, Patel NT, Gessner W, Brossi A (1985) Metabolism of the neurotoxin in MPTP by human liver monoamine oxidase B. FEBS Lett 186:224-228.

Fujii H, Shinya E, Shimada T (1992) A GC box in the bidirectional promoter is essential for expression of the human dihydrofolate reductase and mismatch repair protein genes. FEBS Lett 314:33-36.

Garrick NA, Murphy DL (1982) Monoamine oxidase type A: differences in selectivity towards norepinephrine compared to serotonin. Biochem Pharmacol 31:4061-4066.

Grichnik JM, French BA, Schwartz RJ (1988) The chicken skeletal alpha-actin gene promoter region cxhibits partial dyad symmetry and a capacity to drive bidirectional transcription. Mol Cell Biol 8:45874597.

Grimsby J, Lan NC, Neve R, Chen K, Shih JC (1990) Tissue distribution of human monoamine oxidase A and B mRNA. J Neurochem 55:1166-1169

Grimsby J, Chen K, Wang LJ, Lan NC, Shih JC (1991) Human monoamine oxidase $A$ and $B$ genes exhibit identical exon-intron organization. Proc Natl Acad Sci USA 88:3637-3641.

Johnston JP (1968) Some observations upon a new inhibitor of monoamine oxidase in brain tissue. Biochem Pharmacol 17:1285-1297.

Johnson P, Friedmann T (1990) Limited bidirectional activity of two house keeping gene promoters: human HPRT and PGK. Gene 88: 207-213.

Joseph LJ, LeBeau MM, Jammison GA, Acharya S, Shows TB, Rowley JD, Sukhatme VP (1988) Molecular cloning, sequencing and mapping of EGR-2, a human early growth response gene encoding a protein with "zinc-binding finger" structure. Proc Natl Acad Sci USA 85:7164-7168

Kageyama R, Pastan I (1989) Molecular cloning and characterization of a human DNA binding factor that represses transcription. Cell 59: $815-825$

Kageyama R, Merlino GT, Pastan I (1988) A transcription factor active on the epidermal growth factor receptor gene. Proc Natl Acad Sci USA 85:5016-5020.

Knoll J, Magyar K (1972) Some puzzling pharmacological effects of monoamine oxidase inhibitors. In: Advances in biochemical psychopharmacology, Vol 5, Monoamine oxidase-new vista (Costa E, Sandler M, eds), pp 393-408. Now York: Raven.

Lan NC, Heinzmann C, Gal A, Klisak I, Orth U, Lai E, Grimsby J, Sparkes R, Mohandas T, Shih JC (1989) Human monoamine oxidase $\mathrm{A}$ and $\mathrm{B}$ genes map to Xp11.23 and are deleted in a patient with Norrie disease. Genomics 4:552-559.

Lewinsohn R, Glover W, Sandler M (1980) Development of benzylamine oxidase and monoamine oxidase $A$ and $B$ in man. Biochem Pharmacol 29:1221-1230.

Linton JP, Yen J-YJ, Selby E, Chen Z, Chinsky JM, Liu K, Kellems RE, Crouse GF (1989) Dual bidirectional promoters at the mouse dhfr locus: cloning and characterization of two mRNA classes of the divergently transcribed Rep-1 gene. Mol Cell Biol 9:3058-3072.

Means AL, Farnham PJ (1990) Transcription initiation from the dihy- 
drofolate reductase promoter is positioned by HIP1 binding at the initiation site. Mol Cell Biol 10:653-661.

Michael RB, Kadonaga JT, Bell SP, Tjian R (1986) Purification and biochemical characterization of the promoter-specific transcription factor, Sp1. Science 234:47-52.

Mitchell PJ, Wang C, Tjian R (1987) Positive and negative regulation of transcription in vitro: enhancer-binding protcin AP-2 is inhibited by SV40 T antigen. Cell 50:847-861.

Nguyen QT, Doyen N, d-Andon MF, Rougeon F (1991) Demonstration of a divergent transcript from the bidirectional heavy chain immunoglobin promoter VH44l in B-cells. Nucleic Acids Res 19:53395344.

Ozelius L, Hsu Y-PP, Bruns G, Powell JF, Chen S, Weyler W, Utterback M, Zucker D, Haines J, Trofalter JA, Conneally PM, Gusella JF, Breakefield XO (1988) Human monoamine oxidase gene (MAOA): chromosome position (Xp21-p11) and DNA polymorphism. Genomics 3:53-58.

Rizzo MG, Ottavio L, Travali S, Chang CD, Kaminska B, Baserga $R$ (1990) The promoter of human proliferating cell nuclear antigen (PCNK) gene is bidirectional. Exp Cell Res 188:286-293.

Saffer JD, Jackson SJ, Thurston SJ (1990) SV40 stimulates expression of the trans-act factor $\mathrm{Spl}$ at the mRNA level. Genes Dev 4:659666.

Saffer JD, Jackson SP, Annarella MB (1991) Developmental expression of Spl in the mouse. Mol Cell Biol 11:2189-2199.

Shimada T, Fujii H, Lin H (1989) A 165-base pair sequence between the dihydrofolate reductase gene and the diversely transcribed upstream gene is sufficient for bidirectional transcription. Mol Cell Biol $8: 4587-4597$.

Smale ST, Baltimore D (1989) The "Initiator" as a transcription control element. Cell 57:103-113.

Smith ML, Mitchell PJ, Crouse GF (1990) Analysis of the mouse Dhfr/Rep-3 major promoter region by using linker scanning and internal deletion mutations and DNase 1 footprinting. Mol Cell Biol 10:6003-6012.
Somma MP, Gambino I, Lavia P (1991) Transcription factors binding to the mouse HTF9 housekeeping promoter differ between cell types. Nucleic Acids Res 19:4451-4458.

Telerman A, Dodemont $H$, Degraef $C$, Galand P, Bauwens S, VanOostveldt P, Amson RB (1992) Identification of the cellular protein encoded by the human Wilms' tumor (WT1) gene. Oncogene 7:25452548.

Thorpe LW, Westlund KN, Kochersperger LM, Abell CW, Denney RM (1987) Immunocytochemical localization of monoamine oxidase A and $B$ in human peripheral tissues and brain. $J$ Histochem Cytochem 35:217-236.

Tipton KF, O'Carroll AM, McCrodden JM (1987) The catalytic behavior of monoamine oxidase. J Neural Transm [Suppl] 23:25-35.

von Korff RW (1979) Monoamine oxidase: unanswered questions. In: Monoamine oxidase: structure, function, and altered functions (Single TP, von Korff RW, Murphy DL, eds), pp 1-7. New York: Academic.

Wang JC (1979) Helical repeat of DNA in solution. Proc Natl Acad Sci USA 76:200-203.

Weichselbraun I, Ogris E, Wintersberger E (1990) Bidirectional promoter activity of the $5^{\prime}$ flanking region of the mouse thymidine kinase gene. FEBS Lett 275:49-52.

Westlund KN, Denney RM, Kochersperger LM, Rose RM, Abell CW (1985) Distinct monoamine oxidase A and B populations in primate brain. Science 230:181-183.

Youdim MBH, Heldman E, Pollard HB, Fleming P, McHugh E (1986) Contrasting monoamine oxidase activity and tyramine induced catecholamine release in PC12 and chromaffin cells. Neuroscience 19: 1311-1318.

Yu PH, Hertz L (1982) Differential expression of type A and B monoamine oxidase of mouse astrocytes in primary cultures. J Neurochem 39:1492-1495.

Zhu QS, Grimsby J, Chen K, Shih JC (1992) Promoter organization and activity of human monoamine oxidase (MAO) A and B genes. J Neurosci 12:4437-4446. 